\title{
VÁLTOZÁSBAN: AZ ÖNKÉNTESSÉG ÉRTÉKEI
}

Paul Dekker, Loek Halman (eds.): The Values of volunteering. Cross-cultural perspectives. Kluver Academic/Plenum Publishers, New York, Boston, Dordrecht, London, Moscow 2003

\section{DOI: https://doi.org/10.53585/OnkSzem.2021.4.132-139}

Tizennyolc évvel ezelőtt, 2003-ban jelent meg a Paul Dekker és Loek Halman által szerkesztett kötet. Általában a recenzió rovatokban nem szokás közel két évtizede kiadott könyveket, tanulmányokat ismertetni. The Values of volunteering. Cross-cultural perspectives c. kötet azonban semmit nem veszített aktualitásából - mi sem bizonyítja ezt jobban, hogy a Researchgate-en csak az előszót 1600-an hivatkozták le azóta - ezért is tartjuk fontosnak mostani bemutatását.

A könyv máig ható újdonsága az átfogó szociológiai szempontú áttekintés mellett, hogy kiemelt figyelmet szentel az értékek és az önkéntesség kapcsolatának, mind mikro-, mind makroszinten. Egyrészt, részletesen foglalkozik az önkéntesség kapcsán a szolgáltatáscentrikus attitűddel és a reciprocitás kérdésével, valamint az önkéntesség és a demokrácia kapcsolatával. Másrészt az önkéntesség elméleti kérdései (definíciói, motivációi, mikro- és makroszintű meghatározó tényezői, az önkéntesség és az értékek kapcsolata) mellett több országot (és kultúrát) átívelő empirikus vizsgálatok eredményeit is bemutatja. Külön tanulmányok szólnak Európáról, a posztkommunista országokról, a romániai, a norvégiai, a kanadai, az amerikai és a mexikói helyzetről. A kötet nemcsak a szervezeti keretek között zajló önkéntességet vizsgálja, hanem az informális önkéntességet is, és nem köti össze azt csupán a nonprofit szektorral.

\footnotetext{
1 Fényes Hajnalka (PhD) közgazdász-szociológus, egyetemi docens, Debreceni Egyetem Szociológia és
} Szociálpolitika Tanszék 
A kötet tanulmányait négy témakör köré csoportosítva mutatjuk be, és a témakörök ismertetése kapcsán kitérünk azok jelentőségére és esetleges kritikájára, valamint arra, hogy mennyiben aktuális a mondanivalója napjainkban, illetve, hogy számunkra milyen újdonságot jelentett.

\section{AZ ÖNKÉNTESSÉG DEFINÍCIÓS KÉRDÉSEIRŐL}

A kötetben számos tanulmányban előkerült a definíciós kérdés. A szerzők a közös vonásokat kiemelve, az önkéntesség legfontosabb jellemzőjének tartották, hogy:

- nem kötelező tevékenység;

- mások (egyének, szervezet vagy az egész társadalom) érdekében történik;

- nem jár érte fizetség;

- általában szervezett keretek között folyik.

Voicu és Voicu elemzésükben ${ }^{2}$ az önkéntességet ennél szűkebb értelemben, formális (szervezeti) keretek között zajló, mások, vagy az egész társadalom érdekében folyó tevékenységnek tekintették, amely önkéntes, és nem jár jövedelemmel.

A könyv második tanulmányában Meijts et al. ${ }^{3}$ az önkéntesség nyolc országban honos definíciójának hasonlóságait és különbségeit is elemezte. Ötven tevékenységet rangsoroltak aszerint, hogy az mennyiben tekinthető önkéntességnek. A rangsor elején és végén hasonló elemeket találtak mind a nyolc országban, noha azért voltak kisebb különbségek is (például India és a többi ország között a kulturális különbségek miatt mutatkozott nagyobb eltérés). A tanulmány megállapítása a részletes elemzés alapján az volt, hogy az önkéntesség definiálása széleskörű konszenzuson nyugszik.

Fontos még megjegyezni, hogy a köznyelvben elfogadott definícióval szemben egyes szerzők (Meijts et al. és Voicu-Voicu) kiemelték, hogy az önkéntesség nem tisztán altruista tevékenység, mivel az önkéntesség egyéni haszonnal is jár. Annál inkább tekinthetünk egy

\footnotetext{
${ }^{2}$ Voicu, Malina - Voicu, Bogdan: Volunteering in Romania: A rara avis. (pp. 143-160)

${ }^{3}$ Meijts, Lucas - Handy, Femida - Cnaan, Ram - Brudney, Jeffrey. - Ascoli, Ugo - Ranade, Shree. - Hustinx, Lesley

- Weber, Suzanne - Weiss, Idit: All in the eyes of the beholder? Perceptions of volunteering ecross eight countries. (pp. 19-34)
} 
tevékenységet önkéntesnek, ha minél inkább meghaladják az önkéntes saját költségei (a ráfordított szabadidő/munkaidő) a tevékenységgel járó saját hasznot.

\section{AZ ÖNKÉNTESSÉG MOTIVÁCIÓIRÓL}

A motivációkkal foglalkozó tanulmányok szerint az önkéntesség motivációi lehetnek belső indíttatású, egyéni személyiség jellemzők (például segítőkészség, aktivitás, nagylelkűség), de külső indíttatásúak is (például a befolyásoló körülmények, mások viselkedésének hatása). Így tehát, altruista és egoista motivációk egyaránt okozhatják az önkéntes tevékenységet, és napjainkban egyre inkább a racionális motívumok dominálnak.

Wollebaeck és Selle ${ }^{4}$ megállapításai szerint Norvégiában (de a fejlett országok többségében is) az új típusú önkéntesség volt a jellemző, amely specializáltabb, kevésbé ideologikus és kisebb a szervezeti kötődés, mint a tradicionális, elsősorban érték alapú önkéntesség esetén. Az ezredforduló után kimutathatóvá vált, hogy a kulturális és a szabadidős önkéntesség, a sport szervezetek, a fogyatékosokat támogató szervezetek, a szomszédsági csoportok jelentősége nőtt. Az új típusú önkéntesség érdekes és értelmes elfoglaltságot ajánl, cselekvésorientált, rövid időtartamú elkötelezettséggel jár, de az önkéntes szervezetekben erős a fluktuációt okoz. A szerzők szerint az önkéntes munka típusában bekövetkezett változások hátterében az egyéni értékek változása állt.

A kötet negyedik fejezetében Inglehart ${ }^{5}$ interpretálja Putnam ${ }^{6}$ amerikai eredményeit, miszerint a fiatalok körében csökkent, míg az idősek körében viszont nőtt az önkéntesség. Az okokat keresve felmerült, hogy a fiatalok általában kevésbé preferálják az önkéntességet (életciklus-hatás), illetve az is, hogy a 2000-es évek fiataljai kevésbé végeznek majd önkéntes munkát idősebb korukban is (generációs váltás). Inglehart a két hatást ugyan nem tudta szétválasztani vizsgálatában, de eredményei szerint nem az önkéntesség csökkent a kétezres években, hanem annak típusa. A fiatalok új, rugalmasabb, kevésbé állandó szervezeti keretek között végeztek önkéntes tevékenységet (főleg karitatív és sport szervezetekben).

\footnotetext{
${ }^{4}$ Wollebaeck, Dag - Selle, Per: Generations and organizational change. (pp. 161-178)

${ }^{5}$ Inglehart, Ronald: Modernization and volunteering. (pp. 55-70)

${ }^{6}$ Putnam, Robert (2000): Bowling alone: The collapse and revival of american community. New York: Siman and Schuster
} 
Butcher ${ }^{7}$ az önkéntesség „,hasznával”, a segítők és a segítettek közti humanisztikus viszonnyal foglalkozott mexikói példák alapján. Mexikóban korábban az önkéntesség elsősorban morális és/vagy vallásos kötelezettség volt, és az önkéntességet tradicionálisan paternalista viszony jellemezte. Azonban az ezredfordulón megfigyelhető lett a szolgáltatás-centrikus attitűd elterjedése, melynek eredményeként nőtt a bizalmi légkör, élvezetesebb és termékenyebb kapcsolat jött létre az önkéntes és a segítettek között, szemben a korábbi „csak” segítő attitǔddel, ahol nem feltétlenül érvényesült ez a kapcsolati reciprocitás.

Áttekintve a definíciós és motivációs kérdésekkel foglalkozó tanulmányokat két témával érdemes kiegészíteni a 18 évvel ezelőtti elemzéseket. Egyfelől, az elmúlt két évtizedben a magyar oktatási rendszerben megjelent a „kötelező önkéntesség”, ami az egyik definíciós szempont (a nem kötelező jelleg) tágítása mellett szól. A középiskolai közösségi szolgálat, illetve a felsőoktatásban kreditért végzett önkéntes munka (például a service learning kurzus vagy szakmai gyakorlat) összességében nem igazi önkéntesség, de növeli a későbbi, „,valódi” önkéntesség esélyét. Ez a folyamat Nyugat-Európában és a tengeren túl már az ezredforduló előtt is beindult, de erről a kötetben még nem olvashattunk tanulmányt.

A másik téma, az önkéntesség azon attribútuma, hogy az elsősorban „mások javára” végzett tevékenység. Ennek a definíciós szempontnak a tágítása már megjelent a könyvben, szó volt az önkéntesség individualista motivációiról is - föként a szabadidős (kulturális intézményekben, sportszervezetekben végzett) önkéntesség és a posztmodern önkéntesség (ahol maga a részvétel a fontos), illetve a rövid elkötelezettséggel járó egyéb önkéntes tevékenységek kapcsán -, de a karrierépítő és kapcsolatépítő motivációk nem kerültek a kutatói figyelem fókuszába.

\section{AZ ÖNKÉNTESSÉG MAGYARÁZÓ ELMÉLETEI}

A „társadalmi erőforrás elmélet” szerint a nagyobb gazdasági tőke (például a jövedelem), a nagyobb humán tőke (például az iskolázottság), illetve a nagyobb társadalmi tőke (például a kapcsolathálók kiterjedtsége, a szervezeti tagság, a politikai kötődés, a vallási- közösségi

\footnotetext{
${ }^{7}$ Butcher, Jacqueline: A humanistic perspective on the volunteer-recipient relationship: A mexican study. (pp.
} 111-126) 
aktivitás) növeli az önkéntesség valószínúségét. Voicu- és Voicu által bemutatott, Romániára vonatkozó eredmények szerint az erős kötések jelenléte (rokoni, szoros baráti kapcsolatok) és az önkéntes tevékenység között nincs érdemi kapcsolat, de a gyenge kötések (távoli ismerősök, munkahelyi kapcsolatok, társadalmi osztályokon átívelő kapcsolatok), és az emberek közti bizalom elősegítik az önkéntességet. Emellett kimutatták azt is, hogy az iskolázottabb, gazdagabb, fiatalabb, vallásosabb, és a városi lakosok hajlamosabbak az önkéntességre.

Hodgkinson $^{8}$ a társadalmi erőforrás elmélet alapján a kapcsolati tőke hatását vizsgálta részletesebben. Eredményei jórészt igazolták az erőforrás-elmélet előrejelzéseit: a vallásos aktivitás, az önkéntes szervezeti tagság, a kapcsolathálók kiterjedtsége (családi- és baráti kapcsolatok), a politikai aktivitás szoros kapcsolatban voltak az önkéntességgel, bár a politikai aktivitással - a várakozásokkal ellentétben - viszonylag gyenge volt a kapcsolat.

Az önkéntességet magyarázó elméletek egy másik része azon értékek hatásával foglalkozott, amelyek egyéni és csoportszinten is befolyásolják az önkéntességet. Egyéni szinten az altruizmus, a szolidaritás, a reciprocitás, az igazságosság, a mások segítése, az egyenlőség és egyenlőtlenséghez való viszony hatott az önkéntes tevékenység előfordulására. Azonban az önkéntesség jellegét az individualizmus terjedése is befolyásolja, és ennek hatására az önkéntesség új formái terjedtek el. Az értékek össztársadalmi szinten is hatnak az önkéntességre, és emellett az önkéntesség vissza is hat a társadalomban érvényesülő értékekre: erősítheti a demokráciát.

Az értékek makroszintű hatásával kapcsolatban, a negyedik fejezetben Inglehart a kulturális változás (az indusztriális társadalomból a posztindusztriális társadalomba való átmenet) befolyását vizsgálja az önkéntességre. Ezt a gondolatmenetet folytatja Reed és Selbee ${ }^{9}$, akik azt elemzik, hogy Kanadában mennyiben különböznek az önkéntesek - értékeikben és eszményeikben - a nem önkéntesektől. Eredményeik szerint kicsi volt a különbség az önkéntesek és nem önkéntesek értékválasztásai között, de a rendszeres önkéntesek és a nem önkéntesek, illetve a formális és informális önkéntesek között nagyobb különbségeket találtak (például a nagylelkűségben, az állampolgári elkötelezettségben és a közjó iránti érzékenységben).

\footnotetext{
${ }^{8}$ Hodgkinson, Virginia: Volunteering in global perspective. (pp. 35-54)

${ }^{9}$ Reed, Paul - Selbee, Kevin: Do people who volunteer have a distinctive ethos? A canadian study. (pp. 91-110)
} 
Salamon és Sokolowski tanulmányának ${ }^{10}$ középpontjában a "társadalmi eredet elmélet” áll, miszerint az önkéntesség a szélesebb társadalmi- és szervezeti erők és intézmények függvénye, és azokban az országokban gyakoribb, ahol fejlettebb a nonprofit szektor. Az önkéntesség tehát, nemcsak önkéntes választás, vagy spontán altruizmus következménye, hanem befolyásolják a szélesebb társadalmi és intézményrendszeri hatások is.

Az önkéntesség makroszintű magyarázata során a tanulmányok egy része azt vizsgálta, hogy a társadalmi berendezkedés típusának, a GDP nagyságának, a szabadság mértékének és a nonprofit szektor fejlettségének milyen hatása van az önkéntességre.

Kutatásaimban a mikroszintű magyarázó tényezőkkel kapcsolatos hipotéziseim alapját jelentették az itt olvasott tanulmányok, sőt mivel voltak több országot átfogó vizsgálataim, az országok közti különbségeknél a makroszintű tényezők hatásával kapcsolatban is jó alapot nyújtottak. Amit hiányoltam, hogy a motivációkat meghatározó tényezőkről nem esett szó, igaz a szakirodalomban elsősorban pszichológusok foglalkoztak ezzel, és napjainkban is hiányoznak az ezzel kapcsolatos szociológiai szempontú elemzések. Összességében úgy gondolom, hogy a könyv, noha 2003-ban jelent meg, de az itt szereplő magyarázó elméletek a jelenlegi kutatások hipotéziseihez is megfelelő alapot tudnak biztosítani.

\section{AZ ORSZÁGOK KÖZÖTTI KÜLÖNBSÉGEK}

Salamon és Sokolowski számára a társadalmi eredet teória megalapozásához azok az eredmények szolgáltak igazolásul, amelyeket az 1991 és 1999 között végzett nemzetközi összehasonlító nonprofit kutatások alapoztak meg. Az összehasonlító vizsgálatok kitértek az önkéntesség népességen belüli arányának vizsgálatára, amely a legmagasabb az északeurópai, a legalacsonyabb pedig a kelet-európai és latin-amerikai országokban volt az 1990-es évek végén. Az önkéntes tevékenységek között a szociális szolgáltatások, a kultúra és rekreáció voltak a leggyakoribb területek.

Hodgkinson ugyancsak összehasonlító országelemzések alapján vizsgálta az önkéntesség mértékét és az önkéntes tevékenység típusait (jóléti típusú önkéntesség, vallásos

\footnotetext{
${ }^{10}$ Salamon, Lester - Sokolowski, Wojciech: Institutional roots of volunteering: Toward a macro-structural theory of individual voluntary action. (pp. 71-90)
} 
szervezetekhez kötődő önkéntesség, sport stb.). Figyelemre méltó eredménye, hogy az önkéntesség mértékét nem magyarázza egyértelműen sem a politikai berendezkedés típusa, sem a GDP nagysága, sem a szabadság mértéke vagy a nonprofit szektor fejlettsége.

A tizenegyedik fejezetben Halman ${ }^{11}$ azt tárta fel, hogy időben miként alakultak az önkéntesség trendjei a fejlett országokban. Azt találta, hogy az önkéntesség összességében nem nőtt, de nem is csökkent Nyugat-Európában 1980 és 1999 között, és a generációk (fiatalok, idősek) önkéntessége között sem volt jelentős különbség. A szerző annak a kérdésnek a vizsgálatára is kitért, hogy egyrészt egyéni szinten fennáll-e a kapcsolat az önkéntesség és a demokratikus attitűd között. Másrészt az önkéntes szervezetek száma, a gazdasági fejlettség, a vallásos kultúra, a demokrácia hagyománya országonként hogyan hatnak az önkéntességre. Eredményei szerint az önkéntesség és a demokrácia között nem volt kölcsönös összefüggés sem egyéni, sem országos szinten. Az önkéntesek valamivel magasabb értékeket értek el a demokratikus attitűd skálán, mint akik nem végeztek önkéntes tevékenységet (az életkor, a nem és az iskolázottság kontrollálása után is), de a hatás igen gyenge volt (noha az iskolázottság hatása erős a demokratikus attitűdre). Azonban a demokrácia években mért hossza és az emberi jogok helyzete az adott országban erős pozitív kapcsolatban állt az önkéntesség gyakoriságával.

Juknevicius és Savicka ${ }^{12}$ tanulmánya szerint Közép- és Kelet-Európában a rendszerváltás után csökkent a szocialista rendszert jellemző erőltetett, sokszor kötelező jellegű önkéntesség, és nőtt az új szervezetekben zajló „önkéntes alapú” önkéntesség. Ez a növekedés azonban nem volt töretlen. A civil társadalom erősödésével a rendszerváltásokat követő években gyorsan nőtt az önkéntesség, majd a változások után ezek a folyamatok lelassultak, sőt az önkéntesség csökkenése volt megfigyelhető. Összevetve a nyugat-európai országokkal, a térségben, az ezredfordulón már igen alacsony volt az önkéntesség. A szerzők Közép- és Kelet-Európa országai közti különbségeket vizsgálva azt találták, hogy az önkéntesség mértékére és típusára három tényező hatott erősen: a kommunista ideológia erőssége a korábbi rendszerben, a demokratikus reformok gyorsasága és a civil szektor kiterjedtsége.

\footnotetext{
${ }^{11}$ Halman, Loek.: Volunteering, democracy, and democratic attitudes. (pp. 179-198)

12 Juknevicius, Stanislovas - Savicka, Aida: From restitution to innovation: Volunteering in the postcommunist countries. (pp. 127-142)
} 
Eliasoph ${ }^{13}$ külön nézőpontot képviselve, egy etnográfiai (résztvevő megfigyeléses) vizsgálat eredményét mutatta be, amit a szerző kétféle önkéntes szervezetben vett fel az Amerikai Egyesült Államokban. A vizsgálat abból a kérdésfeltevésből indult ki, hogy az önkéntesség szélesíti-e a polgárok látókörét és erősíti-e a politikába való bekapcsolódásukat.

Eredményei szerint az önkéntes munka egyre kevésbé generált igazi közösségeket, és az önkéntes tevékenység inkább individuális aktivitássá vált. Fontos megállapítás született a tekintetben, hogy a demokrácia hatása az önkéntességre erősebb, mint az önkéntesség hatása a demokráciára.

${ }^{13}$ Eliasoph, Nina: Cultivating apathy in voluntary associations. (pp. 199-212) 